\title{
Is University Students' Value Orientation toward Integrity Behind Their Decision to Cheat or Not Cheat in Exams?
}

\author{
Anggara Wisesa, ${ }^{1}$ Dematria Pringgabayu, ${ }^{2 *}$ Adita Pritasari, ${ }^{1}$ \\ Dany Mubammad Athory Ramdlany, ${ }^{1}$ and Nurfaisa Hidayanti ${ }^{1}$ \\ ${ }^{1}$ School of Business and Management ITB, Bandung, Indonesia \\ ${ }^{2}$ Politeknik Pajajaran ICB, Bandung, Indonesia
}

\begin{abstract}
Organizational values characterize every activity, including the behavior of the members of an organization, and their decision-making. However, there are moments in which the members of the organization violate the values, even though they know they should not. It also happens to university students. This fact brings us to reflect on how the values are interpreted in value orientation. By employing the phenomenological method using Kohlberg's constructivist theory of moral development stages, this study explored the value orientation towards integrity in business school students' decisions to cheat or not. The result indicates that even for students who face the same decision to cheat or not, their decision is affected by how they understand the value of integrity, which depends on their value orientation and their cognitive moral development. Most respondents had a mindset of egoistic value orientation, which is more concerned with the benefits and payback when making a decision. Most cases happened without there being a prior decision to cheat; the decision is made at the time of the exam by considering the emerging internal or external situational factors.
\end{abstract}

Keywords: cheating; decision making; integrity; value orientation; situational factors

JEL classification: L290, Z000

* Corresponding author’s e-mail: demabayu5@gmail.com 


\section{Introduction}

The growing awareness of the importance of the value of integrity in organizations has made it one of the popular research topics in recent years (Kolthoff et al. 2013). As a fundamental of organizational culture, the values held by an organization are expected to inspire each individual in the way they think, make decisions, beha ve and finally affect the motivation and performance of each individual and the organization (Paarlberg and Perry 2007; McGregor and Doshi 2015). Many researchers discovered how organizational values influence organizational structures (Gorenak and Košir 2012), organizational culture (Diskienë and Goštautas 2010; Janiæijeviæ 2013; Robbins and Coulter 2016), organizational commitment (Cohen and Liu 2011; Arthaud-Day et al. 2012), organizational identity (Aust 2004), organizational strategy (Bansal 2003), work engagement ( $\mathrm{Dyl}^{1} \mathrm{~g}$ et al. 2013), team behavior (Bardi and Schwartz 2003), and team performance, as well as organizational performance (Arthaud-Day et al. 2012; James 2014). Lešnik (in Gorenak and and Košir 2012) argued that organizations make decisions, think that what they think is right, have limitations on what they can do, have moral boundaries, trust, rules, etc.

In spite of organizational values being important for the organization, it is not surprising that believed values are not as well actualized as may be expected within the individuals in an organization (Wisesa 2010). The same phenomenon also occurs in the academic world, in which academic integrity is one of the most important values that every educational institution respects, but in fact cheating, as a form of academic infringement, still occurs. Either intended or unintended, violations of the values or actions which do not comply with those values are considered to be unethical actions and behavior, and encourage all educational institutions to apply strict rules to uphold the value of honesty in every academic activity. Various attempts are being made to overcome these academic violations, but it seems that such violations have become a commonly accepted issue.

In the midst of such an irony, it is a bitter finding that deviant behavior carried out during the study period in university is correlated with deviant behavior at the workplace (Nonis and Swift 2001; Lawson 2004; Ma 2013; Dömeová and Jindrová 2013); there is a strong relationship between cheating at college and unethical behavior at work. Simkin and McLeod (2010) even reported that students who had successfully cheated during an exam or a term paper might be cheating on their company reports. Indeed, students are considered as future business leaders; their ethical preferences are likely to influence the definition of acceptable business ethics. Moreover, their perceptions of what constitutes ethical behavior will affect their actions and business practices in the business world. It is more astonishing to know that students who cheat are actually aware that it is prohibited. They are aware that cheating is a wrongdoing, but they still consciously do it (Wisesa 2010).

Exploring the students' reasons for violating the value of integrity, this paper attempts to answer the question: "Why do university students cheat during exams, even though they know it is wrong?" Cheating is perceived to be a part of their decision-making process, in which their understanding of the value of integrity plays 
an important role. Thus, this paper aims to explore the decision-making process by looking at how students interpret the value of integrity in the academic world.

\section{Literature Review}

\section{Integrity}

Integrity is central to ordinary thoughts about morality (Rosenbaum 2015). Many people view it as a moral virtue (Cox et al. 2003) that is essentially related to other certain moral virtues (Palanski and Yamarrino 2007), such as honesty, fairness, sincerity, or even virtue itself in general. This virtue of honesty seems to be one of the main features of integrity, it is so that acting with integrity and acting ethically is often considered to be synonymous, though literally there is no moral connotation in it (Petrick and Quinn 2000; Six et al. 2007). A number of other studies show a link between honesty and integrity, and also between ethical reasoning and integrity (Berry et al. 2007).

One classic but important and influential work in conceptualizing integrity by Cheshire Calhoun (1995) mentions that there are three major approaches to explain what integrity is: integrated-self, identity, and clean hands. In the integrated-self approach, Taylor (1981) and McFall (1987) see integrity as a form of harmony between various aspects that make up the human self: desire, will, commitment, values, and actions, all of which are coherently integrated as one wholeness. That wholeness is characterized by wholeheartedness (Schoeman 1987). The identity approach to integrity is characterized by an in-depth commitment to self-chosen values, principles, and life projections that reveal one's core identity (Williams 1973, Calhoun 1995).

However it should be criticized that both approaches place too much focus on which condition is referred to as integrity, making integrity a static condition, and ignoring the dynamic character of integrity (Cox et al. 2003). Integrity should be seen as a dynamic process in the formation of self-identity, reflected in the coherence between self-chosen moral values and principles, motivation, and actions, reinforced by a firm commitment to attain those values and principles and not for any other thing (Wisesa 2016a). For possessing integrity, a person needs to continually re-evaluate the values and principles he holds, while still directing it to the realization of universal moral values.

\section{The Mental Process bebind Etbical Action}

In the deontological perspective of morality, it is not the action itself that makes an action be perceived as ethical or unethical. There is nothing called an ethical action in itself, but the consistency between an action and a particular moral principle held by an individual makes an action an ethical action (Wisesa 2016a). An action is not simply physical activity, but it exists because of the mental activity behind it (Piaget 1950/2001, Korsgaard 2009), in both the cognitive and affective aspects. Any action exists for a reason or purpose, and will never exist without a decision to act. Decision-making cannot be separated from the psychological tendencies which lead an individual to face a certain decision (Messick and Bazerman 2001). Without that decision, there would be no structured activity to achieve a goal (Talloo 2007). 
Wisesa et al.

Therefore, it becomes important to note that the ethical aspect of an action should not be seen from the action per se, but from the moral values and principles that become the foundation of the decision to act.

Rest (1986) described that the ethical decision-making process is generated through four stages: ethical sensitivity, ethical reasoning, ethical motivation, and ethical implementation. It reflects that deciding which action to take is not simply a random selection process, but it is based on accurate reasoning with regard to the relevant principles in the reasoning stage. How a person makes a decision reflects what he knows about the world. How he perceives the world affects how he acts, including his motivations for acting (Oyserman, Elmore, Smith 2012) as well as his values and principles that become the basis for acting.

How a person sees value in the action leads him to the fulfilment of a particular need, and that need is the motive that drives the action (Piaget 1968). Thus, all actions are moved because there is a need for something. Since the needs of one person may differ from those of others, the same object can have a different value for different persons. It explains why two persons can have different views and attitudes toward one similar object of value. It also explains why two different persons can have different motivations, even if the action they conduct is similar (Wisesa 2016b). This motivation is what propels a decision to become an action (Rest 1986), and encourages a person to perform certain actions or behavior (Spector 2006).

\section{Cognitive Moral Development and Value Orientation}

Value orientation defines how a value is seen as a value in a person's value system (Wisesa 2016b). Value orientation brings a person to the awareness of what is good in an object (or action); a condition that determines whether an object is good to be pursued (as a value). It determines how a person sees a value as a result of the cognitive and affective responses to the object that has very strong relevance with the construction of intelligence, and it is well reflected in the theory of cognitive moral development by Lawrence Kohlberg (1981). How a person acts when he is facing a moral dilemma is the result of complex interactions between variables such as individual characteristics (including values) and the stage of moral development (Robbins 2005).

Originally what Kohlberg did with his theory is to describe the typology of structures and the forms of common ethical reasoning that can be defined individually, regardless of the ethical decisions and actions that were taken in the process of making the ethical decision. The development of moral consciousness occurs in the process of widening and deepening the aspects to consider when people give moral judgments. The lower the cognitive moral stage, the narrower the criteria used in providing moral judgments. As an individual increasingly matures, he becomes morally more competent in providing moral judgments (Magnis-Suseno 2005). 
The typology consists of two pre-conventional stages, two conventional stages, and two post-conventional stages, as can be seen in Table 1. Altogether there are six stages of development. Each of these levels and phases can be seen as a particular form of moral thinking, or a different view of the socio-moral world. In stage one, for example, people see that what is right is to be obedient to authority and therefore avoid the punishment that may follow from disobedience. What people see as good, or ethically right, in stage one is different to what people see in stage two. People in the second stage of moral development see that what is right is what serves their own needs and satisfies their own desires. Each stage defines what is good in uniquely different ways, and the stages determine how people reason for their decisions and actions.

\section{Table 1. Stages of Moral Development}

\section{Level of Moral \\ Development}

\section{Stage of Reasoning}

Stage 1 (Punishment and Obedience Orientation): individual and moral judgment is motivated by a need to avoid punishment

Pre-conventional

Stage 2 (Instrumental Relativist Orientation): individual and moral judgment is motivated by a need to satisfy one's own desires

Stage 3 (Interpersonal Concordance Orientation): individual's moral judgment is motivated by a need to avoid rejection, disaffection, or disapproval from others

Stage 4 (Law and Order Orientation): individual and moral judgment is motivated by a need not to follow the law to maintain the social order

Stage 5 (Rights and Social Contract Orientation): individual and moral judgment is motivated by respect for the social contract and the rights of others

\section{Post-conventional}

Stage 6 (Universal Moral Principle Orientation): individual and moral judgment is motivated by one's own conscience, applying principles to all humankind and respecting all human life

Source: Kohlberg 1986 (with adaptation) 
This theory explains how moral intelligence is constructively developed and how it determines a person's ability to perform ethical reasoning. The value orientation itself underlies this reasoning; that the reasoning reflects how the person sees and places a value (that becomes a consideration) in front of his need. Value orientation explains how a value can serve a person to meet his need. As the decision is directed to the fulfilment of a need, it means that the act of the decision is directed to a certain "good" because it serves to fulfil the need, whether it is for punishment avoidance, self-interest, close friends, the social order, rights, or universal moral values.

\section{Value Orientation toward Integrity}

Although Kohlberg's typology is not to examine the normative ethical aspect of a decision, Putman (1996) concludes that integrity cannot be formed at all the stages of cognitive development. Egocentric behavior (which is typical in the pre-conventional level of development) cannot support the formation of integrity. Conventional moral development stages are also not strong enough to support integrity, since a person who is adhering to the close group and/or law does not show autonomy when acting. He puts himself under the power of others and society in blind obedience to the rules established by the group. This condition, according to Putman (1996), cannot be used as the basis for integrity.

The signs of integrity appear in the last stage of moral development, in which a person is considered as having moral autonomy (see Piaget 1968), when determining what is good or bad. This reflects his ability to put himself in an equal state with the others, which enables him to see that other people, as human beings, have rights that should be appreciated. Integrity requires this autonomy since it is related to the election of a moral principle autonomously, and to acting based on that principle, especially in a difficult situation. This means that people need to put commitment and motivation into that principle in their action.

The autonomy emphasized by Putman (1996) actually reflects a more fundamental thing. Compared to the mode of moral reasoning in the pre-conventional and conventional stages, the autonomous morality found at the post-conventional stage encourages people to place value and principle as the core values of their core identity (Wisesa 2016a), so that they do not have any other reason to manifest this value and principle except for the value/principle itself - as a terminal value instead of an instrumental value (see Rokeach 1977/2000). The essence of integrity is the process of integrity itself, not the condition it produces (Wisesa 2016a). Thus, an act of integrity is not an action taken, for example, to avoid certain sanctions, for self-benefit over risk, for the expectations of close-friends, or blind obedience to rules, but an action that is directed toward the achievement of the chosen value (and principle), and solely for the sake of that value.

\section{Methods}

This study employed phenomenology to discover the understanding and meanings of the value of integrity behind cheating behavior as a phenomenon of academic infringement. In brief, phenomenology, originated by Edmund Husserl, is a philosophy and qualitative research meth- 
odology to gain the essence or meaning of a phenomenon, and how people experience it. The idea is to get the meaning by reducing that experience to its very meaning or essence (Moustakas 1994). In this context, phenomenology tries to describe the meaning of an individual's experience by exploring the structure of awareness involved in the life experience.

The study was conducted mainly to obtain information about the ethical decision-making carried out by students in a particular dilemmatic exam situation. The respondents were selected by employing the total sampling technique on students from undergraduate classes of 2014 and 2016, and the graduate class of 2016, in a business school in Indonesia. Data collection was done in two steps. The first step was an open-ended questionnaire containing a dilemmatic story following Kohlberg's method, with guidelines provided by Arbuthnot and Faust (1980). Each of the respondents was given a story where they were positioned as the subject in the story. The story was about a final exam and somehow they could not answer the questions, while the situation in the examination room was very conducive for them to cheat. A dilemmatic option was presented to the respondents; they had to choose whether to cheat or not, and they also had to explain the reason for their chosen decision.

The second step was conducted using semi-structured in-depth-interviews with 24 randomly selected students through data saturation sampling. Each interview was designed to explore the reason why the student decided to cheat or not, and the factors that might have influenced their decision. It was also to verify the findings from the first step.
The obtained data were transcendentalphenomenologically reduced (Kockelmans 1994) and then texturally and structurally analyzed following Stevick-Colaizzi-Keen's phenomenological analysis method, as suggested by Creswell (1998). In the textural analysis, the data were categorized into six stages in Kohlberg's typology of moral cognitive development, based on the way each respondent reasoned to cheat or not to cheat. Following the textural analysis, the structural analysis was conducted, by drawing meaning from the categorization to discover what integrity means for the students.

\section{Results}

There were 442 valid questionnaire responses from the three different classes. The data then were analyzed to identify the reasoning mode shown in the given responses, which illustrated how each student orientates the value of integrity, especially when related to the context of cheating. Following Kohlberg's taxonomy and the six stages of cognitive moral development (see Table 1), the responses then were categorized into six categories based on the modes of reasoning reflected in the answers.

In the textural analysis, the phenomenological method was used to get the meaning of each response and to categorize each response into a stage of cognitive moral development, for instance:

“... karena saya takut ketabuan oleh pengawas dan dapat nilai nol" (... because I am afraid of getting caught by the supervisor and get zero score)

By acknowledging its meaning, the statement above reflects the mode of reasoning in stage one of the cognitive moral 
development, as described by Kohlberg (1981; 1986). It mainly considers the consequence of punishment for one's actions. Responses in the same category then were grouped, based on the similarity of their mode of reasoning (the way how individuals respond to a dilemma). The statement above, for example, along with other similar responses, was grouped into the "avoiding sanctions/punishment" mode of reasoning. It reflects that he considered avoiding the punishment in order to respond to the dilemma of whether to cheat or not to cheat. Table 2 shows the result of the textural analysis, explaining how the respondents made their decisions to cheat or not to cheat.

Reflecting on the fact that every decision is made to pursue a needs fulfilment, and needs are related to value (Piaget 1968, 2001) that might be different for different individuals, each mode of reasoning indeed shows how the respondents orient their view of the value of integrity. The modes not only show the difference in how the students justify their decisions, but it indeed reflects their value orientation to honesty as a value that shows how integrity is important to them. It reflects the meaning of the value of integrity to students as a result of their perception of that value of integrity in their daily academic life.

Table 3 shows the mapping of the percentage of respondents with their value orientation. Most of the respondents in all the classes have an instrumental relativist orientation to the value of integrity. It suggests that most respondents see integrity and academic honesty in an egoistic point of view, one where value can bring benefits or harm to themselves and lead to the achievement of their self-interest. The need for self-interest becomes a very basic consideration when making the decision to cheat or not to cheat, meaning that if cheating benefits them, then cheating is the best option to choose. Otherwise, if they see that not cheating benefits them more than cheating, then not cheating is the best choice.

Placing the value of integrity as a means to avoid punishment consistently occupies the second ranks for both of the undergraduate classes, but not in the graduate class, indicating the need to avoid punishment may be less relevant for graduate students than for undergraduate students. Respondents, who have value orientation towards a close friend/group, consider integrity and honesty as a value, as long as both are relevant to the social bond with their close friend/group, either their fellow students or family, and they tend to follow what their peers are doing.

Almost all of the rest of the respondents, who are orientated to universal rules, rights, and moral values, chose not to cheat. Their mindsets are dominated by the awareness of their role as students, the rules, appreciation of others' work, etc. Even though some decide to cheat, they base that decision on the principle of mutualism and the consideration of respective rights. Orientation towards universal moral values is translated as a commitment to a principle, in which they have no other reason besides the principle per se to explain why they decide to cheat or not to cheat. People who possess this value orientation do not see that there is a reason, for example not to cheat, other than because of the value of honesty and upholding the value of integrity. The value becomes the terminal value, and at the same time, the instrumental value. 


\section{Table 2. Value Orientations Toward (Academic) Integrity}

\begin{tabular}{|c|c|}
\hline Value Orientation & Modes of Reasoning \\
\hline $\begin{array}{l}\text { Punishment and } \\
\text { Obedience }\end{array}$ & $\begin{array}{l}\text { - Avoiding sanctions/punishment } \\
\text { - Distracting attention from other things, e.g. blaming the situation } \\
\text { - Not seeing or acknowledging that the actions taken affect others } \\
\text { - Nothing is wrong with the action }\end{array}$ \\
\hline $\begin{array}{l}\text { Instrumental } \\
\text { Relativist }\end{array}$ & $\begin{array}{l}\text { - Considering the benefits of action, including pride } \\
\text { - Comparing the efforts and the risks arising from the decision } \\
\text { - The decision taken depends on the circumstances } \\
\text { - The own self is the most important measure of whether a decision } \\
\text { is taken, regardless of whether it impacts other people or not } \\
\text { - Making use of other people for one's own benefit }\end{array}$ \\
\hline $\begin{array}{l}\text { Interpersonal } \\
\text { Concordance }\end{array}$ & $\begin{array}{l}\text { - Considering close-person's (e.g. parents) exhortation or advice } \\
\text { - Seeing what other people are doing } \\
\text { - Thinking about what a close-person feels about taking action } \\
\text { - Considering pressure of a close person/group }\end{array}$ \\
\hline Law and Order & $\begin{array}{l}\text { - Understanding one's status and role (as a student) as part of } \\
\text { society } \\
\text { - Emphasizing the attention and adherence to the rules and norms } \\
\text { of social institution (education) } \\
\text { - Considering what the public may say about his actions } \\
\text { - Emphasizing the obligations and responsibilities of a student } \\
\text { - Considering whether the action violates the religious rules (sin) }\end{array}$ \\
\hline $\begin{array}{l}\text { Rights and Social } \\
\text { Contract }\end{array}$ & $\begin{array}{l}\text { - Paying attention to the rights existence, either of others or of } \\
\text { themselves } \\
\text { - Considering rewards for efforts made by other people } \\
\text { - Considering whether the action harms other people } \\
\text { - Emphasizing property rights }\end{array}$ \\
\hline $\begin{array}{l}\text { Universal Moral } \\
\text { Principle }\end{array}$ & $\begin{array}{l}\text { - Emphasizing commitment to value or principle as a terminal } \\
\text { value } \\
\text { - Expressing empathy that puts oneself in the position of other } \\
\text { people (golden rule) } \\
\text { - Considering justice, and treating the others fairly and equally } \\
\text { - Emphasizing integrity: conformity and coherence between a } \\
\text { commitment to certain values and principles, as well as actions }\end{array}$ \\
\hline
\end{tabular}




\begin{tabular}{lccc}
\hline \multicolumn{1}{c}{ Value Orientation } & $\begin{array}{c}\text { Undergraduate } \\
\text { Class of 2014 } \\
(\%)\end{array}$ & $\begin{array}{c}\text { Undergraduate } \\
\text { Class of 2016 } \\
(\%)\end{array}$ & $\begin{array}{c}\text { Graduate } \\
\text { Class of 2016 }\end{array}$ \\
\hline Punishment and Obedience & 24.69 & 21.43 & 8.24 \\
Instrumental Relativist & 44.44 & 46.94 & 68.24 \\
Interpersonal Concordance & 8.02 & 13.27 & 8.24 \\
Law and Order & 6.79 & 8.67 & 1.18 \\
Rights and Social Contract & 6.17 & 8.67 & 4.71 \\
Universal Moral Principle & 8.64 & 1.02 & 9.41 \\
\hline
\end{tabular}

From the interview, it was discovered that almost all of the students said that their decision to cheat in the exam was not planned in advance, but the decision just came at that very moment. There are circumstances that cause a shift in the decision, which is characterized by the emergence of situational factors that became a new consideration when making the decision. These situational factors do not appear, or are not identified, before the moment of the exam occurs, so the students do not take those factors into account in their previous decisions.

There are 13 situational factors that encourage students to cheat. Six of them are internal factors: negative mood, feeling lazy about doing the task, students' readiness in the exam, physical health condition, self-confidence in completing the exam, and wrong expectation about the problems given in the exam. The other seven of the 13 factors that encourage students to cheat are external factors, namely the negative effect of the course, the negative effect of lecturers during the course, the nature of the problems in the exam (their difficulty, unattractiveness, and/or having a small percentage of the final score), limited time, supervisor's attitude during the exam, not conducive exam situations, and social environment (classmates).

On the other side, there are 11 situational factors that encouraged the students not to cheat, which are divided into internal factors and external factors. The internal factors are being resigned to fate (related to the exam result), positive self-confidence, positive perceptions of the preparation made for the exam, and the students' understanding of academic rules. The six external factors that encourage students not to cheat are the positive effect of the courses, assertion of rules during the exam, the enforcement of the rules, firm attitude of the supervisors, the exam has different 
Table 4. Situational Factors Affecting Decision to Cheat or Not to Cheat

\begin{tabular}{|c|c|c|}
\hline & $\begin{array}{c}\text { Situational Factors Affecting } \\
\text { Decision to Cheat }\end{array}$ & $\begin{array}{c}\text { Situational Factors Affecting Decision } \\
\text { Not to Cheat }\end{array}$ \\
\hline Internal Factors & $\begin{array}{l}\text { Negative mood } \\
\text { Laziness } \\
\text { Readiness in facing the exam } \\
\text { Physical health condition } \\
\text { Self confidence } \\
\text { Wrong expectation about the } \\
\text { problems given in the exam }\end{array}$ & $\begin{array}{l}\text { Positive mood } \\
\text { Resignation } \\
\text { Self-confidence } \\
\text { Positive perception of preparations } \\
\text { Understanding of academic rules }\end{array}$ \\
\hline External Factors & $\begin{array}{l}\text { Negative effect of the course } \\
\text { Negative effect of lecturers } \\
\text { Attributes of the exam } \\
\text { Limited time } \\
\text { Supervisor's attitude } \\
\text { Surroundings } \\
\text { Classmates }\end{array}$ & $\begin{array}{l}\text { Positive effect of the course } \\
\text { Assertion of rules } \\
\text { Enforcement of rules } \\
\text { Supervisor's attitude } \\
\text { Variation of problems among students } \\
\text { Classmates }\end{array}$ \\
\hline
\end{tabular}

types of problems for different students, and the social environment (classmates). Table 4 describes the situational factors involved in the decision to cheat or not to cheat.

\section{Discussion}

There are two explanations that answer why students violate academic integrity by cheating. First, as is often and commonly alleged, it is because they want to get a good grade. A good grade is seen as a value, something that is valued as academic excellence. For that reason, it is worth the hard effort to achieve it. In fact, there are conditions that can make getting a good grade uncertain, which can be internal or external factors. Facing this, some students stick to the goal (getting a good grade) and place getting a good grade as their want, that they want to get a good grade; and not that they want the good grade because normatively to be good students they should get good grades. Others prioritize completing the exam as soon as possible. That is more important than the results they may obtain. From the interview, it was revealed that not successfully completing a test causes an unpleasant situation for the student, so the top priority is how to get out of this unpleasant feeling as soon as possible, not about the grade.

Facing this difficulty in achieving a good grade, there is a shift in the value structure in the students' minds that usually happens unconsciously. They shift the prioritized value from how to be a good student by getting a good grade to simply how to get the good grade. This places the good grade as the terminal value and opens the instrumental value to the choice of how to get that good grade, in this case by cheating or by not cheating. In the case of cheating, the students placed cheating as the instrumental value, and the way to get a good grade as the terminal value. 
Students know that integrity is one of the main values that must be upheld and the act of cheating is a serious offense. However, their stage of cognitive moral development determines how they see and orientate their perspective toward the value of integrity. It results in how they perceive integrity differently, and this affects them in making a decision regarding the realization of that value. Most students have an instrumental relativist orientation, which encourages them to see the importance of the value of integrity, relative to their need, which can be met by realizing the value of integrity. Whether to act or not to act with integrity (for example being honest) is determined by the evaluation of how honest behavior can lead to the fulfillment of their need.

Placing integrity on a selfless commitment to certain universal moral values or principles carries consequences that only a few of the students who have the potential to gain integrity realize. They have no other reason other than the value or principle they uphold: honesty, fairness, integrity, and others. Their value orientation is only to those values and principles, not to other things such as avoiding sanctions, gaining a good grade, being accepted by friends, following rules, and so on.

Value orientation does not specify what course of action a person will take. Two individuals who have the same value orientation to integrity can commit either to the same action or different actions. It is difficult and not relevant to say that one particular value orientation causes people to cheat or not to cheat. However, the result of the textural analysis reveals that the tendency to cheat is dominant in the group of instrumental relativists (38.7\%).

An interesting thing in this phenomenon is that at the beginning the students did not have any plan to cheat, but in the realization, they cheated. The emergence of these situational factors (see Trope and Liberman 2003) has the potential to make students re-evaluate and change their early decisions about not cheating during the exam, especially when their commitment is not too strong. Its situational nature causes these factors to be difficult to predict early on. Be it internal or external, they all can influence an individual's decision to cheat or not. As internal factors, people are not always aware of these factors, making it difficult to presume that they exist. Dealing with external factors is even more difficult. A person may control their internal factors because of their free will and commitment, which allows them to control it, but it is not so with the external factors. External factors come from the external environment, and people cannot control their emergence.

Finally, when the students make decisions that are contrary to the norm, when they decided to cheat, they make a rationalization for their actions. This rationalization confirms that at that time cheating was the right thing to do, even it is wrong in accordance with the academic norm. This rationalization is a form of self-attempt to recreate the consistency within oneself, which was disturbed because of the cognitive dissonance (Festinger 1962) that arises from making a decision that is contrary to the norm. In summary, the ethical decisionmaking process behind this phenomenon is described in Figure1. 
Figure 1. How Value Orientation Affects Decision

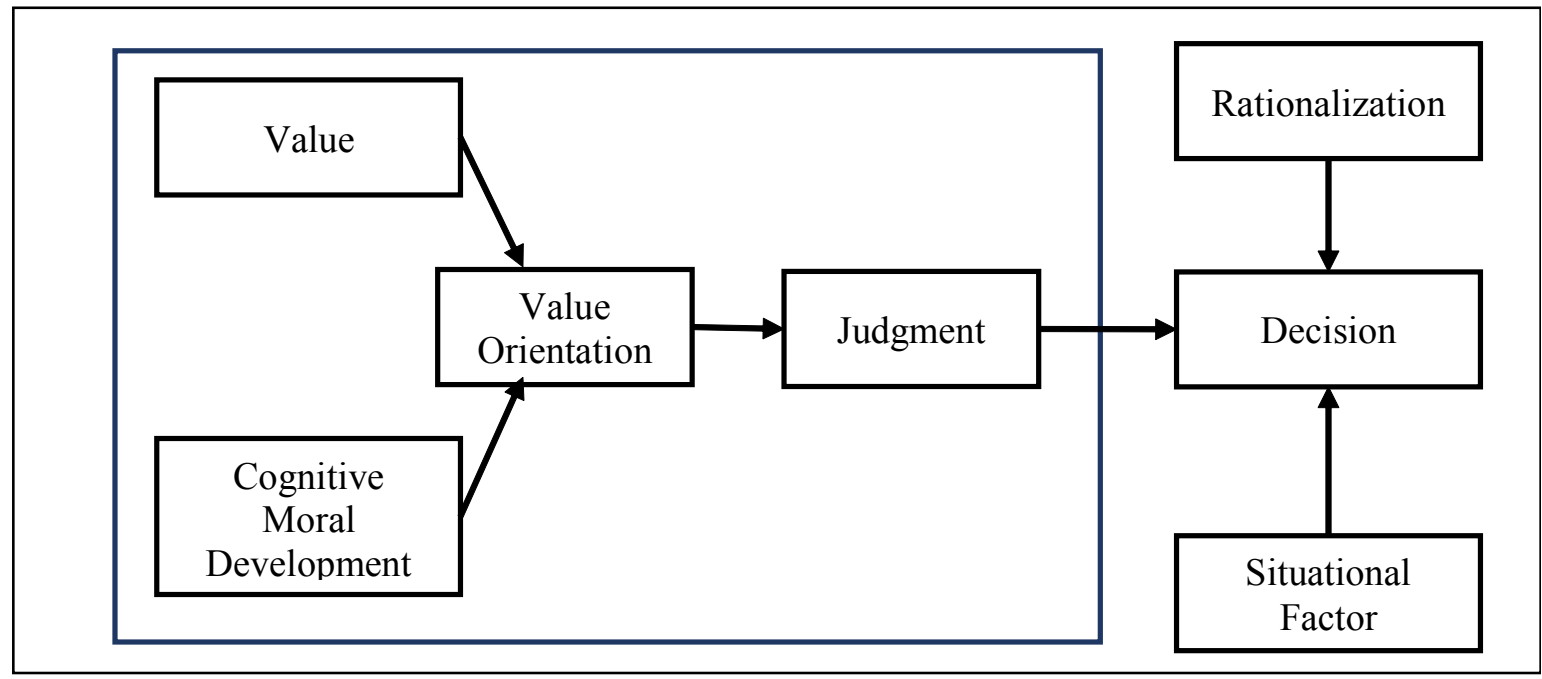

Unlike the Platonic tradition of thought (which, for example, is continued by Piaget 2001 and Korsgaard 2009), knowing what is good is not sufficient for a person to do good (Mackie 1990). Making a decision, by itself, is not enough to move a person to act. It also explains why students commit to cheating during the exam, even though they knew it is forbidden. The key is in the value orientation, namely how they interpret a certain value, and this is influenced by their moral intelligence. It is the individual's orientation to value, not the value itself, which plays an important role in the judgment process that results in a decision and action. The decision is reinforced by rationalization, especially when the decision is not in line with the norm. Sometimes, the decision is re-evaluated, due to the emergence of situational factors driven by environmental and contextual changes, as a form of adaptation mechanism (see Piaget 1968, 2001). Not infrequently, situational factors affect (either change or strengthen) the decision that has been taken earlier.

\section{Business Implications}

Issues of ethics have increasingly become more important in organizations and one of the main challenges in the 21st century business setting. Understanding why students decide to cheat, in spite of their acknowledgment that cheating is normatively wrong, can be an insight into how value orientation plays role in shaping an individual's ethical decisions and actions in the larger scope of the organization.

Lawson (2004) said that the belief that unethical behavior in the business world is prevalent could, in fact, lead to such behavior. Thus the belief among many business students that unethical behavior is widespread in the business world, and is necessary in order to advance their careers, is a cause for concern. The findings of many studies (eg. by Simkin and MecLeod 2010, and Isakov and Tripathy 2017) could lead to this belief becoming a self-fulfilling prophecy in the business world. It becomes crucial for business schools to help students understand and internalize ethical values 
and behavior, so they will carry over this ethical behavior into their future $(\mathrm{Ma}$ 2013). The values instilled in the college, including those concerning ethical values, will influence the way students perceive that these values will not only benefit themselves, but also benefit the organizations where they work later.

The key word is value orientation. An inappropriate orientation process towards values will make a person gain different meanings about the boundaries of behavior that are considered morally good or bad in the organizational environment. Organization members may become more focused on the desire to complete tasks quickly than on how to achieve them in ethical ways. An employee can develop coping mechanisms to justify behavior that might appear to be immoral, such as committing fraud for the company's benefit. In the end, the decision made by the employee is not in line with their company's values. Reflecting on this, it becomes important for organizations to ensure that the value orientation process is carried out well. It is not only about understanding the values at the cognitive level, but also developing a plan to help all members of the organization internalize these values appropriately, so they have the same view about expected behavior.

How people's behavior is affected by how people orient their moral values (as reflected in their value orientation) criticizes the conventional way used by managers to deal with people's behavior in their organization. The reward and punishment method, for example, would only be effective for people whose value orientation is to punishment and obedience, but it might not be effective for people who have a different value orientation. Socializing values and building a reward-punishment system are important, but they cannot be enough. Organizations should be aware of this difference, so they can effectively manage their value-based organizational behavior, to prevent unethical behavior in the organization.

Building the values' initiation and internalization system is necessary. It can encourage every person in the organization to understand what values are in the organization, how those values should be interpreted, why the values are required, what behavior is expected from those values, etc. On the other hand, a working environment that can support a better ethical climate needs to be pursued; one which suppresses the existence of situational factors that encourage unethical behavior, and strengthens the factors that encourage ethical behavior. Both building the values' initiation and internalization system and creating a better ethical climate must be managed on the development of advanced cognitive moral awareness. Therefore individuals can provide ethical judgments and make better ethical decisions in the dilemma situations.

\section{Conclusion}

Every person acts, based on the values that they perceive that underlie their reason to act. The decision of students to cheat or not is based on a variety of reasons, not merely about the academic grade. When students cheat, it is not simply because they do not have integrity. It is more about how students perceive the value of integrity, and that depends on their value orientation toward the value, which is how they assign the value of integrity in their decision. Most students who were respondents for this research orientate the 
value of integrity and honesty to the fulfillment of their own self-interest. Most of the rest orientate their view on sanction/ punishment. A few perceive the value of integrity and honesty from the perspective of rules and their position as students, the consideration of rights, and as a terminalvalued principle. In some cases, the decision to cheat appears without being decided beforehand, because of emerging factors in the situation.

However, this study has some limitations. First, this study only uses a singlequestion questionnaire that may lack in identifying the exact moral development stages mastered by the respondents. A more detailed questionnaire is suggested, to measure the moral development stages that reflect the value orientation. Second, this study does not examine whether situational factors really affect the decisionmaking process, and how much value orientation affects the decision, compared to the situational factors. Third, the proposed model was built in the higher education context. How the model could be used in other contexts should be investigated. Future research may investigate the validity of the model and may expand the usage of the method used in this research to other contexts, for example, business organizations or government institutions, where the value of integrity matters.

\section{Acknowledgememt}

This work was supported by the Research Grant Program 2017 from the School of Business and Management - Institut Teknologi Bandung (SBM - ITB) and was presented in the International Conference on Management in Emerging Markets (ICMEM) 2017.

\section{References}

Arbuthnot, J. B., and D. Faust. 1980. Teaching Moral Reasoning: Theory and Practice. New York: Harper and Row.

Arthaud-Day, M. L., J. C. Rode, and W. H. Turnley. 2012. Direct and contextual effects of individual values on organizational citizenship behavior in teams. Journal of Applied Psychology 97 (4): 792-807.

Aust, P. J. 2004. Communicated values as indicators of organizational identity: A method for organizational assessment and its application in a case study. Communication Studies 55 (4): 515-534.

Bansal, P. 2003. From issues to actions: The importance of individual concerns and organizational values in responding to natural environmental issues. Organization Science 14 (5): 510-527.

Bardi, A., and S. H. Schwartz. 2003. Values and behavior: Strength and structure of relations. Personality and Social Psychology Bulletin 29 (10): 1207-1220.

Berry, C. M., P. R. Sackett, and S. Wiemann. 2007. A review of recent developments in integrity test research. Personnel Psychology 60 (2): 271-301.

Calhoun, C. 1995. Standing for something. The Journal of Philosopby 92 (5): 235-260.

Cox, D., M. La Caze, and M. Levine. 2003. Integrity and the Fragile Self. London: Ashgate. 
Creswell, J. W. 2006. Qualitative Inquiry and Research Design: Choosing Among Five Approaches (2nd ed.). Thousand Oaks: Sage Publications.

Diskienë, D., and Goðtautas, V. 2010. Relationship between individual and organizational values and employees' job satisfaction. Current Issues of Business and Law 5 (2): 295-319.

Dömeová, L., and A. Jindrová. 2013. Unethical behavior of the students of the Czech University of Life Sciences. International Education Studies 6 (11): 77-85.

Dyl $^{1}$ g, A., M. Jaworek, W. Karwowski, M. Koçusznik, and T. Marek. 2013. Discrepancy between individual and organizational values: Occupational burnout and work engagement among white-collar workers. International Journal of Industrial Ergonomics 43 (3): 225-231.

Festinger, L. 1962. A Theory of Cognitive Dissonance. Stanford: Stanford University Press.

Frankfurt, H. 1987. Identification and Wholeheartedness - Responsibility, Character, and the Emotions: New Essays in Moral Psychology. New York: Cambridge University Press.

Gorenak, M., and S. Košir. 2012. The importance of organizational values for organization. Proceeding of Management, Knowledge, and Learning International Conference 2012: 563-569.

Isakov, M., and A. Tripathy. 2017. Behavioral correlates of cheating: Environmental specificity and reward expectation. PLOS ONE 12 (10): e0186054. https://doi.org/10.1371/ journal.pone.0186054

James, P. S. 2014. Aligning and propagating organizational values. Procedia Economics and Finance 11: 95-109.

Janiæijeviæ, N. 2013. The mutual impact of organizational culture and structure. Economic $A n$ nals LVIII (198): 35-60.

Kohlberg, L. 1981. The Philosophy of Moral Development: Moral Stages and the Idea of Justice. San Francisco: Harper and Row.

Kohlberg, L. 1986. The just community approach to corrections. Journal of Correctional Education 37: 57-58.

Kolthoff, E., M. Macaulay, and F. Anechiarico. 2013. Introduction: Integrity systems for safeguarding ethics and integrity of governance. International Review of Administrative Sciences79 (4): 593-596.

Korsgaard, C. M. 2009. Self-Constitution: Agency, Identity, and Integrity. Oxford: Oxford University Press.

Lawson, R. 2004. Is classroom cheating related to business students' propensity to cheat in the 'real world'? Journal of Business Ethics, 49 (2): 189-199.

$\mathrm{Ma}, \mathrm{Z}$. 2013. Business students' cheating in classroom and their propensity to cheat in the real world: A study of ethicality and practicality in China. Asian Journal of Business Ethics 2 (1): 65-78.

Mackie, J. L. 1990. Ethics: Inventing Right and Wrong. London: Penguin Books.

Magnis-Suseno, F. 2005. Pemikiran Karl Marx: Dari Sosialisme Utopiske Perselisihan Revisionisme. Jakarta: Gramedia.

McFall, L. 1987. Integrity. Ethics 1: 5-20. 
Gadjah Mada International Journal of Business - Jan.April, Vol. 21, No. 1, 2019

McGregor, L., and N. Doshi. 2015. How company culture shapes employee motivation. Harvard Business Review. Retrieved from https://hbr.org/2015/11/how- company-culture-shapes-employee-motivation.

Messick, D. M., and M. H. Bazerman. 2001. Ethical leadership and the psychology of decision making. Research in Ethical Issues in Organizations 3, 213-238.

Moustakas, C. 1994. Phenomenological Research Methods. Thousand Oaks: Sage Publications.

Nonis, S., and C. O. Swift. 2001. An examination of the relationship between academic dishonesty and workplace dishonesty: A multi-campus investigation. Journal of Education for Business 77 (2): 69-76.

Oyserman, D., K. Elmore, and G. S. Smith. 2012. Self, Self-Concept, and Identity - Handbook of Self and Identity (2nd ed.). New York: Guilford Press.

Paarlberg, L. E., and J. L. Perry. 2007. Values management: Aligning employee values and organization goals. The American Review of Public Administration 37 (4): 387-408.

Palanski, M. E., and F. J. Yammarino. 2007. Integrity and leadership: Clearing the conceptual confusion. European Management Journal 25 (3): 171-184.

Petrick, J. A., and J. F. Quinn. 2000. The integrity capacity construct and moral progress in business. Journal of Business Ethics 23 (1): 3-18.

Piaget, J. 1968. Six Psychological Studies. New York: Random House.

Piaget, J. 2001. The Psychology of Intelligence. London: Routledge.

Putman, D. 1996. Integrity and moral development. The Journal of Value Inquiry 30: 237-246.

Rest, J. 1986. Moral Development: Advances in Research and Theory. New York: Prager.

Robbins, S. P., and M. Coulter. 2016. Management (13th ed.). Pearson Prentice Hall.

Rokeach, M. 2000. Understanding Human Values: Individual and Societal. New York: The Free Press.

Rosenbaum, S. 2015. Recovering Integrity: Moral Thought in American Pragmatism. Lanham: Lexington Books.

Schoeman, F. (Ed.). 1987. Responsibility, Character, and the Emotions: New Essays in Moral Psychology. Cambridge University Press.

Simkin, M. G., and A. McLeod. 2010. Why do college students cheat? Journal of Business Ethics 94 (2): 441-453.

Six, F. E., F. G. De Bakker, and L. W. Huberts. 2007. Judging a corporate leader's integrity: An illustrated three-component model. European Management Journal 25 (3): 185-194.

Spector, P. 2006. Industrial and Organizational Psychology: Research and Practice. New York: John Wiley and Sons.

Talloo, T. J. 2007. Business Organization and Management. New Delhi: Tata McGraw-Hill.

Taylor, G. 1981. Integrity. Proceedings of the Aristotelian Society 55: 143-159.

Trope, Y., and N. Liberman. 2003. Temporal construal. Psychological Review 110: 403-421.

Williams, B. 1973. Integrity - Utilitarianism: For and Against. Cambridge: Cambridge University Press. 
Wisesa, A. 2010. Menerapkan integritas di dalam organisasi. MBA ITB Business Review 5 (1).

Wisesa, A. 2016a. Analisis kritis mengenai integritas diri sebagai posisi dinamis dalam kerangka pikir konstruktivistik Jean Piaget. Doctoral Dissertation. Depok: Universitas Indonesia.

Wisesa, A. 2016b. Cognitive moral development and its relevance in establishing moral integrity in organization. Sains Humanika 1-2: 53-57. 